\title{
Paleopalynological Study of Tiliaceae and Rutaceae Families during Quaternary Period in Elbasan City
}

\author{
1,3Admir Jançe \\ ${ }^{2}$ Gëzim Kapidani \\ ${ }^{3}$ Blerina Pupuleku \\ ${ }^{3}$ Nikoleta Kallajxhiu \\ ${ }^{3}$ Anxhela Dauti \\ 1"Albanian University", Tiranë, Albania \\ 2Tirana University, Tiranë, Albania \\ 3University "Aleksander Xhuvani” Elbasan, Albania. \\ Email: adi_jance@yahoo.it
}

Doi:10.5901/ajis.2015.v4n2s2p19

\section{Abstract}

Palynological data are reported in the present study, obtained in depositions of last XX centuries (last historic period of New Holocene, last Quaternary), from representative stations of Elbasani, important and ancient town in the central Albania. In this article for the first time is provided some paleopalynological data about the dispersion of Tiliaceae and Rutaceae families during Holocene period in the area where is situated Elbasan city. The aim of this paper is to present the correlation between the depth and dispersion of Tiliaceae and Rutaceae families on different periods of time. For this purpose we took some samples from various layers of soil, starting from the surface to four meters depth. Palynological data for these families are given for the first time in the Palynologic literature in our country. The data show a very interesting correlation between the depth and number of spores and pollens for these two families.

Keywords: Paleopalynological, Holocene period, spore, pollen, Tiliaceae, Rutaceae.

\section{Introduction}

The given material presents paleopalynological data of Holocene deposits in Elbasan district.

Pollen and spores can undoubtedly be preserved because the outer wall of the grains is extraordinarily resistant (Kapidani, 1996; Pacini \& Franchi, 1978).

Plant microfossils of these two families have not been studied previously from any of the localities in Elbasan and there aren't any studies by neither native or foreign authors for spore and pollen content data about these plants in Holocene deposits in our country. (Kapidani, 1996; Kapidani \& Jançe, 2004).

Information on the method of collection, preservation and laboratory processing of the pollen grains of these plants were provided by this study as well.

This study provides important information about the reconstruction of paleoflora, paleoclimate, stratygraphy of the Holocene, etc (Fegri, 1957; Davis, 1999).

The study in Holocene deposits also provides the factors which have their impact on the potential transformation of the flora in Elbasan district. (Kapidani \& Jançe, 2004; Muhameti et al., 1984; Moore \& Webb, 1978; Shalla, 1983; Jance \& Kapidani, 2011; Forest et al., 1999).Observations, counting and photos of palynomorphs it was carried on using light microscopes, magnification up to 1000x.

The quantitative data through spores and pollens variety of Rutaceae and Tiliaceae families deposited on the ground shows the direction of evolution of these two families mentioned in the study. (Kapidani, 1996; Kapidani \& Jançe, 2004; Muhameti et al., 1984). 


\section{Materials and Methods}

During this study we have taken 16 soil samples, starting from 4 meters depth to $0.25 \mathrm{~m}$. The distance between the sampling stations is $0.25 \mathrm{~m}$. Palynological examination of all samples showed that all contained a large amount of organic matter that appeared suitable for pollen analysis. For each soil sample we have prepared 20 microscopic preparations.

\subsection{The method of acetolysis according to Erdtman.}

The soil sampling is based on Erdtman method (Erdtman, 1960; 1969). Erdtman acetolyze method consists on processing the material with an acetolyze mixture, acetic anhydride $\left(\mathrm{CH}_{3} \mathrm{COO}\right)_{2}$ and sulfuric acid $\left(\mathrm{H}_{2} \mathrm{SO}_{4}\right)$ in a 9:1 ratio. In order to get better results first mix $1 \mathrm{~cm}^{3}$ soil with $10 \mathrm{ml} \mathrm{KOH}(10 \%)$. After that we cleaned it with distillated water, and then we mixed it with acetolyze solution, until a neutral environment is obtained. The emasculation process is followed by a centrifugal process for three minutes (3000 rotation/minute). After that, granules were placed on slide and were observed with a microscope by dropping a drop from glycerin solution and water in a ratio 1:1.

The acetolyze method is widely used in palynology; it gives better visibility over the spores and pollens compared with the other methods used during the microscopic observation process. (Aleshina, 1964; Erdtman, 1960, 1969; Kapidani, 2005; Kapidani \& Jançe, 2004; Moore \& Webb, 1978; Davis, 1999; Jance \& Kapidani, 2011). We then use this method to assess the paleoclimate and paleoelevation represented by the assemblage and will discuss the results in terms of their implications for the uplift history of the Elbasan region.

\subsection{Fixture of prepared composites.}

The fixture of prepared composites was realized by using the method of glue-preparations through gel-glycerin. The gelglycerin was prepared based on the Kisser method (Kisser, 1935) by using $50 \mathrm{gr}$ of gelatin, $175 \mathrm{ml}$ of distillate water, $150 \mathrm{gr}$ glycerin, $7 \mathrm{gr}$ phenol (crystals). Once the distillate water was heated up to $50^{\circ} \mathrm{C}$, the gel was dropped into it. It was mixed up several times till melted properly. Then the glycerin and the composite were added and boiled till the liquid became thicker and viscose. After the phenol was added to the mixture, a uniform melted composition was taken. The prevention of air bubbles that might emerge during the process of composite preparation was made by warming up in advance all equipment used over the process. The final composite was isolated to the edges of microscope slide with spray or paraffin and after 3 days it was ready to be used and stored.

\section{Results and Discussions}

The maximum number of spores of Tiliaceae family ( 25 spores per sample) is taken in $4 \mathrm{~m}$ of depth while the minimum number is taken in $2.5 \mathrm{~m}$ of depth. Regarding to the Rutaceae family the maximum number of spores (51 spores per samples) is taken close to surface $0.25 \mathrm{~m}$ of depth.

Table 1. Number of spores according to the depth

\begin{tabular}{|c|c|c|c|c||}
\hline \hline Sample & Depth (meters) & Number of spores (Tiliaceae) & Number of spores (Rutaceae) & Total number of spores according to depth \\
\hline 1 & 4 & 0 & 0 & 0 \\
\hline 2 & 3.75 & 0 & 0 & 0 \\
\hline 3 & 3.5 & 0 & 0 & 0 \\
\hline 4 & 3.25 & 0 & 0 & 0 \\
\hline 5 & 3 & 0 & 0 & 0 \\
\hline 6 & 2.75 & 0 & 0 & 0 \\
\hline 7 & 2.5 & 10 & 0 & 10 \\
\hline 8 & 2.25 & 12 & 0 & 12 \\
\hline 9 & 2 & 12 & 0 & 12 \\
\hline 10 & 1.75 & 12 & 0 & 12 \\
\hline 11 & 1.5 & 17 & 0 & 17 \\
\hline 12 & 1.25 & 18 & 0 & 18 \\
\hline 13 & 1 & 15 & 0 & 15 \\
\hline 14 & 0.75 & 18 & 0 & 18 \\
\hline 15 & 0.5 & 19 & 23 & 42 \\
\hline 16 & 0.25 & 25 & 51 & 76 \\
\hline Total number of spores & 158 & 74 & 232 \\
\hline
\end{tabular}


On table 1 are presented the data about the number of spores for both two Tiliaceae and Rutaceae families according to the depth. Also is presented and the total number of spores for each of two families.

On figure 1 is clearly shown a small increasing or the steady number of spores of Tiliaceae family from the $2.5 \mathrm{~m}$ of depth towards the surface except in the depth $0.25 \mathrm{~m}$.

While regarding to the Rutaceae family, representatives of this family are present only in two samples of surface, respectively 0.5 and $0.25 \mathrm{~m}$ also is clearly shown the increasing number of spores for this family above all near to the surface.

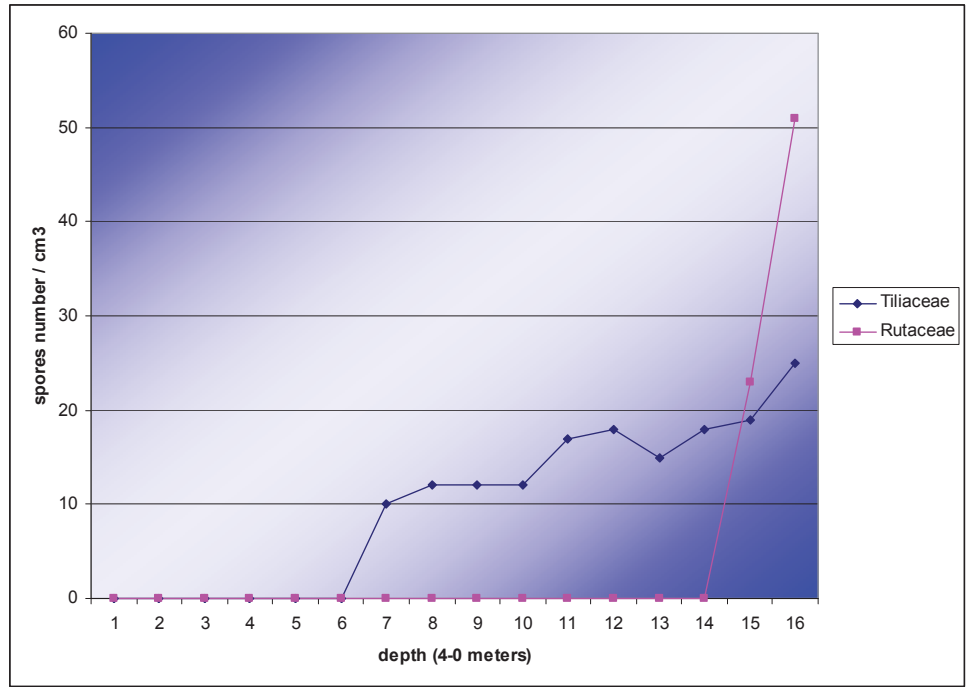

Figure 1. The spore's dispersion of Tiliaceae and Rutaceae families according to the depth

Based on the data presented in table 1 and figure 2 the spore's total number of Tiliaceae family is greater than that of Rutaceae family, respectively 158 and 74 spores.

Based on the microscopic analyzes the most of the 158 spores or pollens of Tiliaceae family belong to Tilia Type (Photos 1, 2, 3), as for the Rutaceae family almost of the 74 spores found and analyzed belong to the Citrus Type (Photos 4, 5). all depths.

From the survey results of Table 1 for all stations noted that, not all palynomorphs for both families are present at

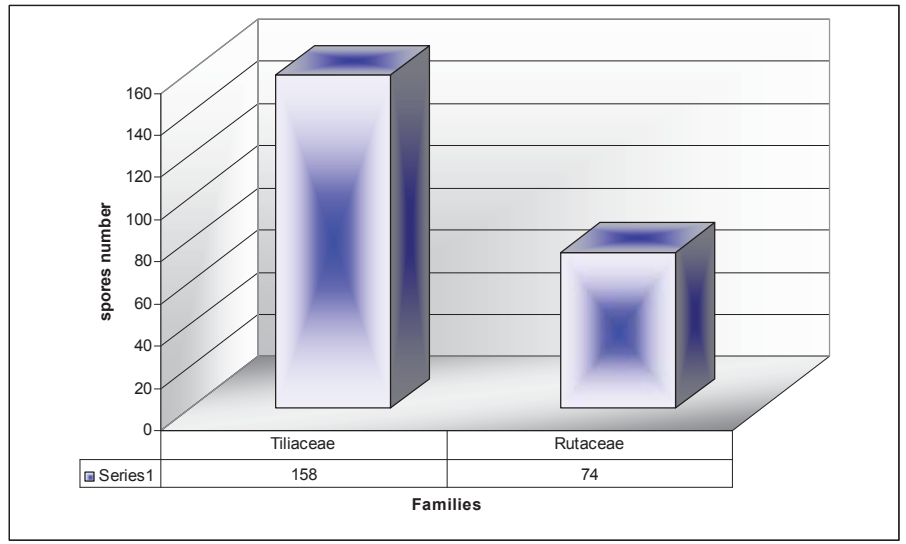

Figure 2. The total number of spores according to Tiliaceae and Rutaceae families 
In sample 16 , belonging to 0.25 meters depth the number of spores of Tiliaceae family is 25 , as for the Rutaceae family in sample 15 and 16, belonging to $0.5-0.25$ meters of depth the number of spores undergoing a rapid growth.

The dispersion rate of family Tiliaceae spores for different samples is presented (Figure 3).

In the figure 4 is presented the dispersion spores of the Rutaceae family from the bottom to the surface (Photos 4,5 ).

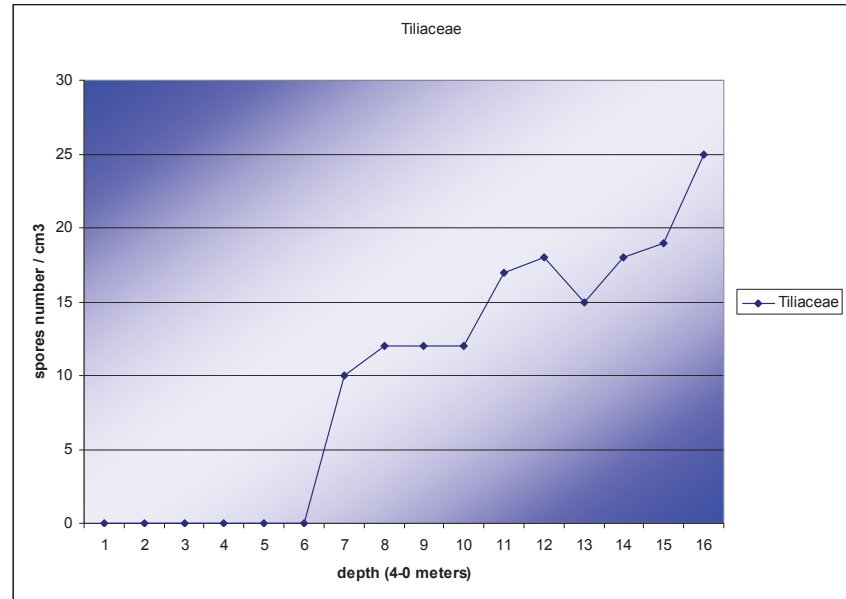

Figure 3. The spore's dispersion of Tiliaceae family according to the depth

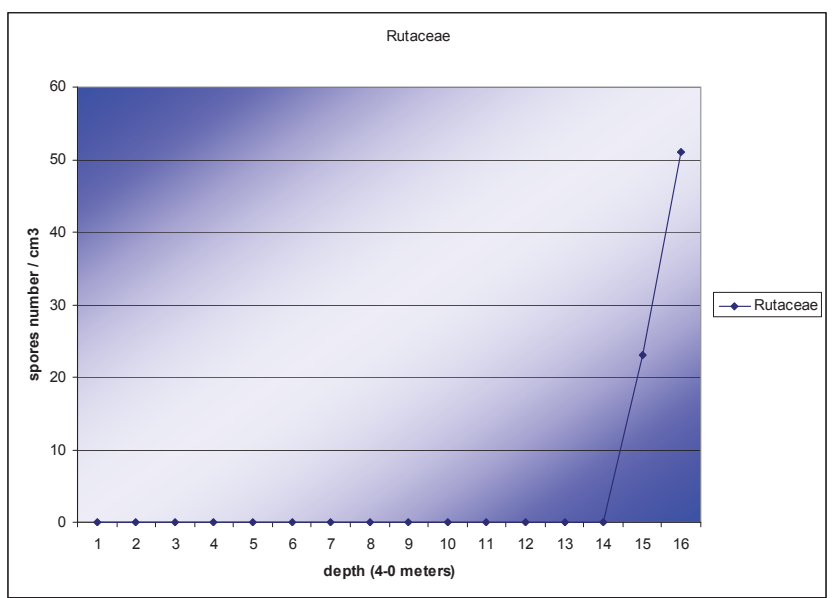

Figure 4. The spore's dispersion of Rutaceae family according to the depth

The steady number of spores of Tiliaceae family maybe shows that: the human factor not had any impact on these plants and these plants during these years keep the same presence, also increasing the number of spores for this family near to the surface may is connected with the cultivation of this family recent years in Elbasan city (Group of authors, 2003).

Palynomorphs type of lime (Tilia) lack of depth $4 \mathrm{~m}$ to $2.75 \mathrm{~m}$ and is present from 2.5 to up to the surface; worth mentioning that the depth of $2.5 \mathrm{~m}$ is dated approximately mid 600 . This plant grows in its natural state far from the city of Elbasan. Based on these data we may say that perhaps linden can be planted as ornamental plants for the city.

Another interesting fact is the presence of palynomorphs type of citrus (Citrus type). These are only found in the depths of $0.5-0.25 \mathrm{~m}$. Increasing the number of spores of Rutaceae family near to the surface may is connected with the cultivation of this family in Elbasan city, 150 years ago.

This fact among other things, leads us to consider in the human role on the cultivation of this plant. Age of sample $0.5 \mathrm{~m}$ estimated approximately circa 1750. Based on this fact one might think that orange and lemon are brought and cultivated in Elbasan about these years. (Group of authors, 2003). 


\section{Conclusions}

1. The total number spores of Tiliaceae family are greater than this of Rutaceae family.

2. The spore's number of Tiliaceae and Rutaceae family is increasing their overall presence from the bottom to the surface.

3. Not all palynomorphs for both families are present at all depths:

- The spore's number of Tiliaceae family shows permanency from 2.5 to up to the surface.

- The spore's number of Rutaceae family increases close to the surface (0.5-0.5 m of depth).

4. Since in Elbasan region not had climate and natural factors that have influenced in the vegetation change; we are mostly of the opinion that vegetation changes reported over the years are mainly related to the impact of human hand cultivation of useful plants.

\section{References}

Aleshina, L.A. (1964). O plici tikvenih. - Bot. Zhurnal, Moskva, 12: 1773-1778.

Group of authors. (2003). Elbasani Enciklopedi. - Sejko, Elbasan, 750 pp.

Erdtman, G. (1960). The acetolysis method. A revised description. Svensk Botanisk Tidskrift, 54: 561-564.

Erdtman, G. (1969). Handbook of palynology. An introduction to the study of pollen grains and spores. Hafner Publishing Company, New York, $486 \mathrm{pp}$.

Fegri, K. (1957). Morfologia pilci dija prakticeskih cellej. - Bot. Zhurnal, Moskva, 1: 20-31.

Kapidani, G. (1996). Bazat e Palinologjisë. - Sejko Infoservis, Elbasan, 230 pp.

Kapidani, G. (2005). Fjalori i Terminologjisë Palinologjike. - Sejko, Elbasan, 149 pp.

Kapidani, G. \& Jançe, A. (2004). Të dhëna të pjesshme mbi studimin e sporeve dhe poleneve në depozitimet e Kuaternarit në qytetin e Elbasanit. - Buletini Shkencor UE, Elbasan, 1: 58-65.

Kisser, J. (1935): Bemerkungen zum Einschluss in Glycerin-Gelatine. Z. wiss. Mikr. Berlin, 51 pp.

Moore, P.D. \& Webb, J.A. (1978). An illustrated Guide to Pollen Analysis. - Hodder and Stoughton, London, 133 pp.

Muhameti, P. \& Gjani, E. \& Roqi, R. (1984). Palinostratigrafia e depozitimeve të Tortonianit në pjesën lindore të Ultësirës pranë Adriatikut në bazë të studimit të sporopoleninit. - Buletini Nafta dhe Gazi, Fier, 204 pp.

Davis, O.K. (1999). Preliminary pollen analysis of Neogene and Quaternary sediment of The Great Salt Lake, U.S.A. - Proceedings Pliocene Conference, AASP Contribution, Arizona, 34: 227-240.

Pacini, E. \& Franchi, G.G. (1978). II polline: Biologia e Aplicazioni. - Quaderni di biologia, Bologna, 12: 8-53.

Shalla, M. et al. (1983). Gjeologjia e Shqipërisë. - Shtëpia Botuese "Naim Frashëri", Tiranë, 343 pp.

Jançe, A. \& Kapidani, G. (2011). Palynological data of Compositae and Umbelliferae families during Holocene Period in Elbasan city - J. Int. Environmental Application \& Science, (JIEAS - 2011), Vol. 6, No. 5: 729-733.

Forest C. E. et al. (1999). Paleoaltimetry incorporating atmospheric physics and botanical estimates of paleoclimate. - Bulletin of the Geological Society of America 111: 497-511

Appendix 1. Microscopic photos

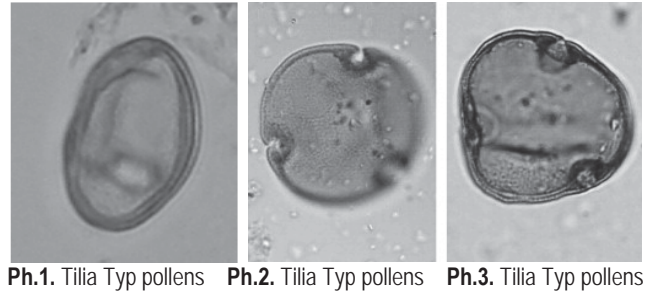

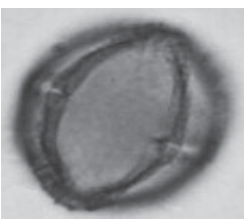

Ph.4. Citrus Typ pollens

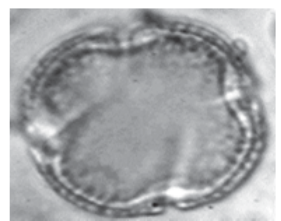

Ph.5. Citrus Typ pollens 